\title{
Correction to: Use of oral contraceptives in BRCA mutation carriers and risk for ovarian and breast cancer: a systematic review
}

\author{
D. Huber ${ }^{1} \cdot$ S. Seitz ${ }^{1} \cdot$ K. Kast ${ }^{2} \cdot$ G. Emons ${ }^{3} \cdot$ O. Ortmann ${ }^{1}$ (D)
}

Published online: 7 October 2021

(c) The Author(s) 2021

\section{Correction to: \\ Archives of Gynecology and Obstetrics \\ (2020) 301:875-884 \\ https://doi.org/10.1007/s00404-020-05458-w}

The article "Use of oral contraceptives in BRCA mutation carriers and risk for ovarian and breast cancer: a systematic review" written by D. Huber, S. Seitz, K. Kast, G. Emons and O. Ortmann was originally published electronically on the publisher's internet portal on March 05, 2020 without open access. With the author(s)' decision to opt for Open Choice the copyright of the article changed to (C) The Author(s) 2020 and the article is forthwith distributed under a Creative Commons Attribution 4.0 International License, which permits use, sharing, adaptation, distribution and reproduction in any medium or format, as long as you give appropriate credit to the original author(s) and the source, provide a link to the Creative Commons licence, and indicate if changes were made. The images or other third-party material in this article are included in the article's Creative Commons licence, unless indicated otherwise in a credit line to the material. If material is not included in the article's Creative Commons licence and your intended use is not permitted by statutory regulation or exceeds the permitted use, you will need to obtain permission directly from the copyright holder. To view a copy of this licence, visit http://

The original article can be found online at https://doi.org/10.1007/ s00404-020-05458-w.

O. Ortmann

olaf.ortmann@klinik.uni-regensburg.de

1 Department of Gynecology and Obstetrics, University Medical Center Regensburg, Regensburg, Germany

2 Department of Gynecology and Obstetrics, Medical Faculty and University Hospital Carl Gustav Carus, TU Dresden, Dresden, Germany

3 Department of Gynecology and Obstetrics, Georg August University Göttingen, University Medicine, Göttingen, Germany creativecommons.org/licenses/by/4.0/. Open Access funding enabled and organized by Projekt DEAL.

The original article has been updated.

Open Access This article is licensed under a Creative Commons Attribution 4.0 International License, which permits use, sharing, adaptation, distribution and reproduction in any medium or format, as long as you give appropriate credit to the original author(s) and the source, provide a link to the Creative Commons licence, and indicate if changes were made. The images or other third party material in this article are included in the article's Creative Commons licence, unless indicated otherwise in a credit line to the material. If material is not included in the article's Creative Commons licence and your intended use is not permitted by statutory regulation or exceeds the permitted use, you will need to obtain permission directly from the copyright holder. To view a copy of this licence, visit http://creativecommons.org/licenses/by/4.0/.

Publisher's Note Springer Nature remains neutral with regard to jurisdictional claims in published maps and institutional affiliations. 